Mountain Air.-With the object just referred to, the next station selected was in the Pyrenees on the Pic Canigou, a barsen mountain 2785 metres in height. The transport of the apparatus to this remote station required six porters and mules, and M. Gautier with his presparateur and one guide were left to make the best of a rock cabin amidst the snow, fires being suppressed in order to avoid contamination of the atmosphere.

Under these cheerless conditions a series of determinations was made which amply realised the anticipation that in the absence of vegetation and soil the proportion of marsh gas would diminish. The quanticy found was 2.19 volumes per 100,000 as against II 3 for the air of woods and $22 \cdot 6$ for the air of Paris.

The quantity of free hydrogen reached 17 parts per 100,000 .

Sea Air. - M. Gautier now decided to get rid of vegetation altogether by going out to sea, and took up his station during the autumn equinox at the iron lighthouse of the RochesDouvres, 40 kilometres from the coast of Brittany. He arrived after a series of north-west gales, and was, he says, altogether tris favorise par les circonstances. Analysis showed a fall in the proportion of carbon to $1 / 33$ of what it was in mountain air, that is, to an almost negligible quantity. There was an increase in the amount of free hydrogen to $19^{\circ} 5$ vols. per 100,000 . It appears, therefore, that the air over the sea and at very high altitudes is nearly free from hydrucarbons, and that it contains two vols. in 10,000 of free hydrogen, a proportion, it will be observed, about two-thirds of that of the atmospheric carbonic acid.

Source of the Gases. - In the concluding section of his memoir, $\dot{M}$. Gautier discusses in more detail the nature of the accessory combustible gases in the air and the origin of atmospheric hydrogen. He concludes that, subject to variations, the com. bustible gases of Paris air may be set down as follows, in volumes per 100,000:-Free hydrogen 19.4, methane 12. I, benzene vapour or analogous compounds $I^{\prime} 7$, carbon monoxide and traces of olefines and acetylenes $\cdot 2$.

It remains now only to show that the presence of hydrocarbons in air is in accordance with established geological facts, and that it is connected with the occurrence of the larger quantities of free hydrogen. M. Gautier points out that methane is exhaled from many soils, that it is the chief constituent of firedamp, that it occurs with petroleum and is emitted by volcanoes, especially by mid volcanoes. Hydrogen often accompanies methane in these cases, and has been found in the fumerolles of Iceland and Tuscany. These outbursts are only extreme manifestations of actions which have been silently in continual progress for ages. The occurrence of hydrogen occluded in rocks has been pointed out by Fouqué and by Tilden. M. Gautier has himself greatly extended earlier researches. He finds that many specimens of granite treated with water at $280^{\circ} \mathrm{C}$. or with dilute acids at $100^{\circ}$, yield a considerable volume of gas. Thus, in one case, a kilogramme of granite heated with diluted phosphoric acid gave the following volumes in c.c. : $-\mathrm{H}_{2} \mathrm{~S} \mathrm{I}^{\prime} 2, \mathrm{CO}_{2} 27^{\circ} \cdot 6, \mathrm{C}_{2} \mathrm{H}_{2}{ }_{12} \cdot 3, \mathrm{CH}_{4}$ trace, $\mathrm{N}_{2}$ (rich in argon) $230^{\circ}, \mathrm{H}_{2} 53$.

It seems protable that when the igneous rocks were solidifying and their components crystallising, they included small quantities of the primitive earth materials which now form the subjacent zone, that is to say, sulphides, nitrides, argonides, heliides, hydrocarbons, carbides, fluorides, iodides, phosphides, arsenides, \&c. These substances, by the action of water, aided or not by acids, gave rise to the observed gases. As to the hydrogen, M. Gautier is assured by experiments, which he does not now detail, that it comes from $(a)$ the action of water at a red heat on ferrous compounds, (b) the destruction by heat of hydrocarbons formed previously by the action of water on metallic carbides, $(c)$ in a less degree by the action of water at a red heat on certain nitrides.

Hydrocarbons come from the action of water on small quantities of metallic carbides, especially those of aluminium and iron, included in the rocks.

Many more details of geological and chemical interest are given by M. Gautier. He insists that it is not necessary to imagine that water penetrates to the molten material lying below the solid crust of the earth. It is sufficient for the water to reach the low layers of rock containing these small quantities of included raw materials. On the other hand, it is not to be supposed that the gaseous products of the action of water on the raw materials will all escape from the surface. Some of the gases will combine with the rocks, and some on reaching the region of oxygen will be oxidised; but others, including methane, the petroleum hydrocarbons, nitrogen and hydrogen, not readily oxidised except at high temperatures, will escape into the air.

M. Gautier deals briefly with the question as to whether the hydrogen will tend to accumulate in the upper regions of the atmosphere. Without committing himself to a definite opinion, he quoles the views of Dr. Johnstone Stoney as to the impossibility of the earth's gravitational attraction being sufficient to retain helium or hydrogen. If the view is accepted that some of the hydrogen molecules at the fringe of the atmosphere have a velocity outwards of II, 000 metres per second, their escape would be possible, and we should have to picture a continual flux of hydrogen from the earth's surface through the atmosphere into interstellar space.

It is interesting to note that Profs. Liveing and Dewar incline perhaps to a different view. They say "if the earth cannot retain hydrogen or originate it, then there must be a continued accession of hydrogen to the atmosphere (from interplanetary space), and we can hardly resist the conclusion that a similar transfer of other gases must also take place."

Whatever view be correct as to the source and retention of atmospheric hydrogen, there can be no longer any doubt not only of its presence but of its abundance, and the establishment of this fact marks an advance in knowledge highly important from many points of view.

A. S.

\section{SCIENTIFIC AGRICULTURE IN THE UNITED} $S T A T E S .^{1}$

A GRICULTURAL experiment stations are now in operation under the act of Congress of March 2, 1887, in all the States and Territories of the United States. Agricultural experiments have been begun in Alaska with the aid of national funds, and an experiment station is in operation in Hawaii under private auspices. In each of the States of Alabama, Connecticut, New Jersey and New York a separate station is maintained wholly or in part by State funds, and in Louisiana a station for sugar experiments is maintained partly by funds contributed by sugar planters. Excluding the branch stations established in the several States, the total number of stations in the United States is 54 . Of these 52 received the appropriation provided for in the act of Congress above mentioned. The total income of the stations is about 1, 143,334 dollars, of which 720,000 dollars was received from the National Government, the remainder, $423,334.93$ dollars, coming from the following sources: State Governments, 240,300.20 dollars; individuals and communities, I 2, 100 dollars ; fees for analyses of fertilisers, 75, 294.42 dollars; sales of farm products, 69, 312.60 dollars; miscellaneous, $26,327.7$ I dollars. In addition to this the Office of Experiment Stations has an appropriation of 40,000 dollars for the past fiscal year, including 10,000 dollars for the Alaskan investigation.

The stations employ 678 persons in the work of administration and inquiry. The number of officers engaged in the different lines of work is as follows:-I)irectors, 71 ; chemists, 148; agriculturists, 68 ; experts in animal husbandry, 9 ; horticulturists, 77; farm foremen, 21 ; dairymen, 23; botanists, 52 ; entomologists, 48 ; veterinarians, 26 ; meteorologists. 17 ; biologists, 7; physicists, 7; geologists, 5; mycologists and bacteriologists, 20 ; irrigation engineers, 5 ; in charge of substations, 16; secretaries and treasurers, 24; librarians, 9 ; and clerks, 43. There are also 48 persons classified under the head of "miscellaneous," including superintendents of gardens, grounds and buildings, apiarists, herdsmen, \&c. Three hundred and eight station officers do more or less teaching in the colleges with which the stations are connected.

During 1899 the stations published 445 annual reports and bulletins, containing 16,924 pages. Besides regular reports and bulletins, a number of the stations issued Press bulletins, which were widely reproduced in the agricultural and county papers. In a recent report on the work and expenditures of the stations, Mr. A. C. True, the Director of the Experiment Station Office, makes the following general statements :-

The work of the stations during the past year has for the most part been along the same lines as heretofore, and in the 1 Abridged from the Experiment Station Record (vol, xi. No. 9), pub ished by the U. S. Department of Agriculture. 
aggregate a large amount of useful work has been accomplished. By their own efforts and with the aid of the colleges of agriculture and the State boards or commissioners of agriculture, the stations are bringing their work home more closely to the farmers through publications, farmers' institutes, agricultural associa tions, home reading courses, and the Press. It is becoming evident that farm practice in the United States is being materially affected by the work of the stations, and they are more and more relied upon by our progressive farmers for advice and assistance.

The wisdom of Congress in making the Hatch fund a research fund is every year becoming more apparent. Thi Department is therefore disposed to more strongly insist on a strict interpretation of this act in this direction, and to hold that it is not only in accordance with the obligation, but also to the interest of the States, to devote the Hatch fund to investigations in agriculture and to supplement this fund as far as may be necessary to promote the interests of agriculture in other lines.

The movement for the improvement of courses of agriculture in the colleges with which the stations are connected is steadily growing. The past year has witnessed many changes for the better as regards specialisation of the work of instruction and the development of courses suited to the varied needs of students. More than ever before, the colleges are reaching out beyond their class rooms and are carrying useful instruction to the farmers through farmers' institutes, correspondence courses, and other forms of so-called university extension. As this outside work becomes better organised it is more apparent that it belongs to the college rather than the station.

As the work of both college and station grows in extent and complexity, it becomes more apparent that in order to perform the most efficient service the station should be organised strictly as a separate department of the institution with which it is connected, and that it should have an organisation so compact that its work may proceed in accordance with a schedule carefully planned and energetically administered. To secure this end experience shows that it is quite desirable that the station should have a competent executive officer, who can devote his time very largely to planning and directing its operations, managing its general business, and representing its interests before the public. It is encouraging to observe that in several States during the past year these considerations have led to the more complete separation of the business of the station from the general business of the college, and to the appointment of a director of the station as a separate officer.

From the very first the stations in the United States have been largely engaged in the inspection of commercial fertilisers, and this work has been so efficiently and usefully conducted that from time to time additional inspection duties have been laid upon the stations. The movement for the establishment of different kinds of inspection service under authority of the National and State Governments is growing apace, and it is very important that the relations of this work to the other functions of the stations should be clearly understoud. Soon after the establishment of the stations under the Hatch Act this Department ruled that the funds appropriated under this Act could not be legitimately applied to pay the expenses of the inspection and control of fertilisers. The same principle holds good with reference to other forms of inspection service dernanded of the stations. While the methods and usefulness of inspection in any particular line are still problematical, it may be justifiable for a station to take up this work to a limited extent, but as soon as it becomes a matter of routine business the State should provide funds for its maintenance. If it seems expedient that any part of the inspection service should be performed by the station under State laws and at State expense, the matter should be so arranged as not in any way to interfere with the investigations of the station. It is a great mistake to divert the time and energy of a competent investigator to the toilsome routine work of inspection service.

The number and importance of the experiments which the stations are conducting in cooperation with practical farmer and horticulturists have greatly increased of late. Thousands of such experiments are now annually conducted in the United States. These range all the way from simple tests of varieties of plants to special experiments in the management of farm or horticultural crops, live stock, or particular operations, such as tobacco curing. It is coming to be more clearly recognised that the field operations in agriculture or horticulture conducted on the station farm need to be supplemented by similar work in a considerable number of lucalities in order to be of general usefulness to the State. By going into different localities, as the needs of its work demand, the station can make itself more useful to the State as a whole. Without doubt cooperative experiments need to be very carefully planned and thoroughly supervised to be successfully conducted, and their success depends on their quality rather than their number. It is encouraging to observe that more careful attention is being given to this important matter by station officers, and it is believed that this work may be made much more economical and useful than the permanent substations as ordinarily managed.

\section{UNIVERSITY AND EDUCATIONAL INTELLIGENCE.}

OXFORD. - In consequence of the death of Sir John Conroy, a tutorial fellowship in chemistry and physics, to be held in conjunction with the Bedford Lectureship, is announced at Balliol College. The fellow elected will be expected to supervise the whole science teaching of the College and to give instruction in chemistry and elementary physics. Applications, with the names of three persons to whon reference may be made, must be sent to the Master on or before April 18 .

Profs. E. A. Minchin and A. Sedgwick have been appointed public examiners in zoology.

Scholarships in nalural science are announced for June 18 at Merton Coll

CAMbridge. - The Smith's Prizes are awarded to Mr. G. H: Hardy and Mr. J. H. Jeans, of Trinity College. Mr. P. V. Bevan, of the same College, receives honourable mention. The prizemen were second and fourth wranglers respectively in 1898 . $\mathrm{Mr}$. Bevan was fourth wrangler in 1899 .

Mr. L. Doncaster, of King's College, is nominated to the University table at the Naples Zoological Station.

Miss Meyer has presented to the Geological Museum the valuable collections made by her brother, the late Mr. C. J. A. Meyer.

THE senate of Glasgow University has resolved to confer the honorary degree of LL.D. upon Prof. A. W. Ruicker, Sec. R.S., at the graduation ceremony on April 23.

THE council and senate of University College, Liverpool, has passed a resolution "that any measure dealing with the organisation and control of secondary education should provide for the direct representation of Universities. and University colleges in the local authorities which such Bill may establish."

THE chair of natural philosophy in the University of Edin. burgh will become vacant on April 29, in consequence of Prof. Tait's resignation. The patronage of the chair is vested in the curators. Applications, with relative testimonials, should be lodged with Mr. R. Herbert Johnston, secretary to the curators, at 4, Albyn Place, Edinburgh, on or before June I.

THE annual general meeting of the Association of Technical Institutions, adjourned in consequence of the death of the Queen, will be held at the Fishmongers' Hall, London, on Tuesday, April 16, when the president, Sir Swire Smith, will take the chair and the president-elect, the Right Hon. Sir William Hart Dyke, M.P., will deliver an address.

From the ninth annual report of the Technical Instruction Committee of the City of Liverpool we derive the following facts as to valuable scientific instruction and work assisted by the committee. A course of four lectures was given on "Elec. tric Vibrations," by Prof. O. J. Lodge, F.R.S., and a course of five lectures on "Oceanography," by Prof. Herdman, F.R.S. Both courses proved very successful in achieving the main object for which they were designed, viz., to bring before teachers of schools and classes some of the results of the progress of modern science, and to illustrate the methods and lines upon which this progress is proceeding. Admission to the courses was free to teachers of schools and classes in Liverpool. In 1900 the committee again renewed their grant (of rool.) in aid of the scientific work carried on by the Lancashire Sea Fisheries Joint Committee. A permanent Sea Fisheries Laboratory in the Zoological Department of the University College, under the direction of Prof. Herdman, is partly supported by this grant ; and trained assistants are constantly at work in this laboratory investigating fisheries' questions they may arise in

No. I637, VOL. 63] 